\title{
COSTS, BENEFITS, AND TAX-INDUCED DisTORTIONS OF STOCK OPTION Plans
}

\author{
RAINER NIEMANN \\ DIRK SIMONS
}

CESIFO WORKING PAPER NO. 815

CATEgORY 1: Public FinANCE

DECEMBER 2002

\footnotetext{
An electronic version of the paper may be downloaded

- from the SSRN website: www.SSRN.com

- from the CESifo website: www.CESifo.de
} 


\title{
COSTS, BENEFITS, AND TAX-INDUCED DISTORTIONS
}

\begin{abstract}
In recent years stock option plans (SOPs) have become an important component of managerial remuneration in most industrialized countries. Commonly accepted, corporate as well as individual taxes have a major impact on the costs of a SOP. In contrast, the tax influence on the benefits of a SOP remains widely unperceived. This article deals with both -cost and benefit- aspects simultaneously by integrating taxation into a principalagent model, where the agent is compensated in options. Deriving the optimal quantity of options to be granted and the optimal exercise price to be set, resulting profits for managers and shareholders can be quantified. Comparing the results in a tax-free world to the results taking into account different levels of taxation several tax-induced incentive distortions can be identified.
\end{abstract}

Keywords: stock options, principal-agent, taxation.

JEL Classification: D82, H25, M41.

Rainer Niemann

Department of Economics

University of Tuebingen

Mohlstrasse 36

72074 Tuebingen

Germany

rainer.niemann@uni-tuebingen.de
Dirk Simons

Dept of Business Administration and

Economics

University of Bielefeld

P.O. Box 100131

33501 Bielefeld

Germany

dsimons@wiwi.uni-bielefeld.de 


\section{Introduction}

Long-term incentive plans (LTIs) have become an important component of managerial remuneration within the last decade. Companies in countries like Australia, Canada, France, U.K. or the U.S. have already considerable experience with LTIs. In recent years, this kind of remuneration is increasingly applied by corporations located in other countries, too, e.g., in Belgium, Germany, Italy, the Netherlands or Spain (Towers Perrin, 2001). Although there exist various forms of equity based compensation, like phantom stocks, restricted stocks or stock appreciation rights, the overwhelming number of firms using LTIs relies on stock options (Towers Perrin, 2001). For example, in the U.S. nowadays the remuneration in options exceeds the sum of salary and bonus payments by a multiple (Hall, 1999). In Germany, the legislative lifted the ban of granting naked options to managers in 1998, enabling the implementation of stock option programs (SOPs) as they are internationally known. Subsequently, the number of German firms making use of this compensation alternative increased significantly (Bernhardt, 1999).

Typically, the popularity of SOPs is explained by two different arguments (Smith and Watts, 1982). On the one hand, compensating managers in options ties their remuneration to their firm's stock-market price which is thought to align managers' and shareholders' interests. On the other hand, it is conjectured that SOPs are advantageous from a tax perspective. E.g., in the U.S. under a non-qualified stock option plan the manager's tax liability is deferred until he exercises his options and the employer is allowed to deduct the exercise gain realized by his manager as a business expense. Given the firm's tax rate exceeds the manager's one a SOP is mutually beneficial, because the resulting tax advantage can be distributed among managers and shareholders. However, for a clear-cut analysis it is necessary to focus on the combined tax liability of managers and shareholders, taking into account taxes on the corporate level.

The goal of our paper is to consider costs and benefits of a SOP simultaneously. For this reason, we provide a comprehensive analysis by recognizing incentive as well as tax 
effects. Therefore, we model three levels of taxation: taxation of managerial remuneration, deductibility of SOP costs on the corporate level, and capital gains taxation on the shareholders' level. The applied principal-agent model reveals that the decision to implement a SOP is distorted by taxation. This holds for all tax regimes under consideration. As expected, the implementation of a SOP may be prevented due to increased costs. However, especially under asymmetric capital gains taxation, the opposite is possible, too. Further, the optimal SOP conditions might be distorted as well. E.g., given deductibility of SOP costs on the corporate level, the optimal strike price can be reduced as a result of tax considerations.

The remainder of the paper is organized as follows. The next section provides a literature review of explanations for the application of SOPs. Further, tax regimes differing with respect to the treatment of SOPs are introduced. In the third section, we formulate a principal-agent model and derive the optimal SOP conditions for the pre-tax situation. This solution serves as a benchmark for the results obtained in the different post-tax cases presented in the fourth section. Further, all tax regimes analyzed in this paper are illustrated by an example in the appendix. The last section concludes.

\section{Empirical evidence on granting and taxing stock options}

\subsection{Reasons for granting stock options}

Despite the widespread use of SOPs a commonly accepted economic justification has not yet emerged. The three most prominent presumptions are that

1. SOPs align the objectives of management and shareholders,

2. start-up firms substitute salary by SOPs in order to reduce cash-outflows

3. the grant of SOPs is motivated by tax considerations. 
The first presumption is scrutinized by empirical studies, which observe the stock price reaction after the implementation of a SOP or LTI plan has been announced. The idea of this approach is to analyze, whether potential shareholdes value the firm higher due to expecting an increased management quality. Unfortunately, the results from these studies are ambiguous. Larcker (1983, pp. 18 and 27) finds a positive stock price reaction. However, his study suffers from a small sample size. Kumar and Sopariwala (1992, p. 570) find a positive stock price reaction as well. Findings by Brickley et al. (1985, pp. 122) and Gaver et al. (1992, pp. 175 and 179) do not correspond, as they are not able to identify any significant stock price movement around the announcement date. Nevertheless, this does not indicate the uselessness of SOPs, as the findings might be explained by restricted information processing capacities of the market participants. Alternatively, given strongly efficient capital markets the implementation of the SOP (LTI) might have been anticipated before the announcement, meaning that the price adaptation has taken place before the data collection started. DeFusco et al. (1990, pp. 620 and 624) control for changes in stock's volatility which is another proxy for the effectiveness of SOPs. As expected, an increasing volatility after SOP announcements was observed. This finding confirms that managers are motivated to invest less conservative, which is in the interest of welldiversified shareholders. Recent studies by Aboody (1996) and Ferris et al. (1998) seem to confirm the effectiveness of SOPs as well, although Aboody finds that a positive price reaction on a SOP announcement is followed by a negative one during the options' lifetime. In general, the incentive and interest aligning hypothesis seems to be acceptable.

Empirical evidence supporting the second hypothesis is given in Yermack (1995, p. 263), who finds that firms will substitute cash payments by option grants if they are in a bad liquidity position. The findings by Matsunaga (1995, p. 2) and Kulatilaka and Marcus (1994, p. 46) can be interpreted analogously, because they state that profits of start-ups shown in the P\&L would be reduced up to $50 \%$ if the firms had to expense the SOP costs according to an option pricing model. Further, several studies based on the seminal paper 
of Smith and Watts (1992) find that the granting of SOPs and the growth opportunities feasible to a firm are positively correlated (Baber et al., 1996, p. 301; Gaver and Gaver, 1995, p. 30; Collins et al., 1995, p. 44; Bizjak et al., 1993, p. 352). But their results can be interpreted in two different ways. On the one hand, firms with growth opportunities could be regarded as young start-ups, meaning the liquidity-based reasoning is supported. On the other hand, it could be argued that companies with growth opportunities rely on intangible assets like management's know-how, resulting in an informational asymmetry between managers and shareholders, giving the management the opportunity to decide opportunistically. Thus, the implementation of SOPs can be regarded as an instrument for aligning objectives, supporting the first presumption.

The last presumption is supported by two empirical studies conducted by Hite and Long (1982) and Long (1992). They find that changes in the U.S. tax code are followed by changes in the design of SOPs (see also Smith and Watts, 1982, pp. 150). Summing up, empirical evidence for each presumption can be found. However, the second one is not able to explain the widespread use of SOPs especially among mature firms. Thus, we will focus on the interest aligning and the tax hypothesis.

\subsection{Various tax regimes}

As has been stated in the introduction a clear-cut analysis requires to analyze the combined tax burden on the managerial, corporate, and shareholder level. However, tax regimes vary widely over different countries. Thus, it is necessary to identify the most important tax features for each taxational level:

1. On the manager's level, most importantly, it has to be considered when the options are taxed as ordinary income and whether the favourably purchased stocks are subject to -possibly preferential- capital gains taxation when sold in advance.

Referring to the first point up-front taxation has to be distinguished from exercise taxation. Under an up-front regime the options are taxed when they are granted. 
The tax base is defined as the options' market value determined either by an option pricing method or a rule of thumb. Under exercise taxation, the exercise profit, defined as the difference between the stock price $S_{E}$ in the instant of exercise, $t_{E}$, and the strike price $X$, is taxed in $t_{E}$. Additionally, profits from selling the acquired stocks in $t_{S}$ might be taxed as capital gains under both regimes.

Most industrialized countries tax upon exercise. Among the few countries practicing an up-front taxation are Belgium, the Netherlands and Switzerland. Some kind of hybrid taxation is practiced in Austria (Knoll, 2002, p. 328). Interestingly, in Brazil options are regularly not taxed as ordinary income (Towers Perrin, 2001, p. 11). Instead, the acquired stock is subject to a capital gains taxation only. In many other countries, the capital gains taxation is applied additionally to an exercise taxation, e.g. in the U.K. or the U.S. Contrary, in Germany or Austria, capital gains resulting from selling the favourably acquired stocks are not generally taxed at the moment. A more detailed overview over the international taxation of SOPs is given in table 3 in the appendix.

2. On the corporate level the most important tax factor is, whether the profit dilution induced by the SOP can be expensed for tax purposes or not. In the U.S., according to a correspondence principle the exercise gains realized by the option-holders are deducted as a business expense (IRC Sec. 83 (h) and Sec. 162). In contrast, e.g. in the U.K. or in Germany, it is prohibited to deduct the SOP-induced profit dilution as a business expense (Bernhardt, 2001, p. 431).

3. For the shareholders' level it has to be considered, whether realized profits from stock price increases are taxed as capital gains. In most countries this is the case, exceptions are Austria, Belgium, Germany and the Netherlands. Some tax codes contain special capital gains tax rules subject to the percentage ownership or the legal structure of the firm. 
The major results from the discussion above are summed up in table 1. Combining the three levels of taxation leads to eight possible constellations, which can be generated by choosing one element of each column:

\section{Table 1}

Combinations of different levels of taxation

\begin{tabular}{l|l|l} 
manager level & firm level & shareholder level \\
\hline $\begin{array}{l}\text { up-front taxation } \\
\text { exercise taxation }\end{array}$ & SOP-costs are deductible & taxation of capital gains \\
SOP-costs are non-deductible & no taxation of capital gains
\end{tabular}

In the following we will neglect the up-front taxation on the manager's level since it is only rarely applied. Apart from the pre-tax case given as the benchmark solution in section 3 the different tax regimes will be presented in section 4 as depicted in the following table:

\section{Table 2}

Tax regimes discussed in this paper

\begin{tabular}{c|cccc} 
section & 4.1 & 4.2 & 4.3 & 4.3 \\
case & Germany & hypothetical & U.K. & U.S. \\
\hline instant of taxation & exercise & exercise & exercise & exercise \\
SOP-costs & not deductible & deductible & not deductible & deductible \\
capital gains & no taxation & no taxation & taxation & taxation
\end{tabular}

Three of the four post-tax cases represent -on an idealized level- the existing tax regimes applied to SOPs in the U.S., the U.K. and Germany.

\section{Assumptions and benchmark solution}

\subsection{Model design}

We consider a listed company which is owned by a large number of shareholders, where a blockholder does not exist. Consequently, the firm is run by its executive managers, who have a discretionary decision scope. The shareholders implement a SOP as a means of aligning interests. Other incentive mechanisms or control devices are not feasible, so that interdependencies between different incentives can be neglected. ${ }^{1}$ 
The situation is analyzed by formulating a principal-agent model. A single principal represents the shareholders, meaning they are assumed to have a commonly shared interest in the firm. Similarly, the executive managers are personated by a single agent. Disregarding conflicting interests within the groups of shareholders and managers highlights potential goal conflicts between these two groups.

We assume the principal to be risk-neutral, whereas the agent behaves risk-averse with respect to compensation, modelled by a power utility function $U(r)=r^{\gamma}$ with $\left.\gamma \in\right] 0,1[$, where $r$ denotes the managerial remuneration resulting from the SOP and $\gamma$ the degree of risk aversion. ${ }^{2}$ Further, the agent suffers from disutility of effort $V^{e}, e \in\{a, 0\}$. We assume that the agent provides a basic effort level compensated by the salary. If the agent is motivated by the SOP to work harder or with a higher quality, respectively, he provides an additional (non-basic) effort inducing a non-negative disutility, $V^{a}>0$. With no additional effort the disutility is $V^{0}=0$. Utility is assumed additive separable in remuneration and effort.

Due to the changed quality of managerial arrangements the agent's effort has an impact on the distribution of the stock price movements. Assuming a discrete probability distribution with three possible states (upward, constant, downward), the following figure 1 depicts the influence of the managerial effort on the stock price movement.

\section{Figure 1}

Probability distributions of the change in firm value, both with and without additional managerial effort

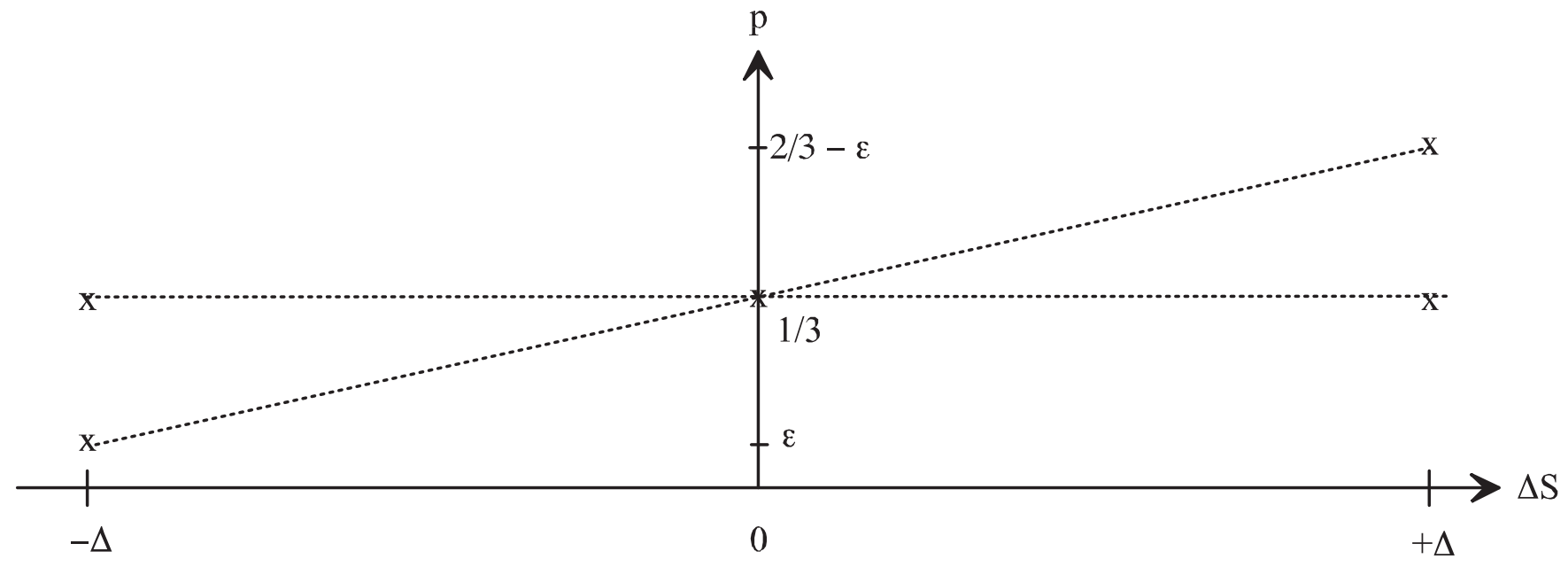


Given no additional effort, all states are equally likely, represented by the following distribution function:

$$
P(\Delta S \mid e=0)=\left\{\begin{array}{l}
p_{L}^{0}=\frac{1}{3} \text { for } \Delta S=-\Delta \\
p_{M}^{0}=\frac{1}{3} \text { for } \Delta S=0 \\
p_{H}^{0}=\frac{1}{3} \text { for } \Delta S=+\Delta
\end{array}\right.
$$

where $\Delta$ is an exogenously-given firm-specific constant representing the possible change of the firm value $\Delta S$. An additional effort increases the probability of an upward and decreases the probability of a downward movement:

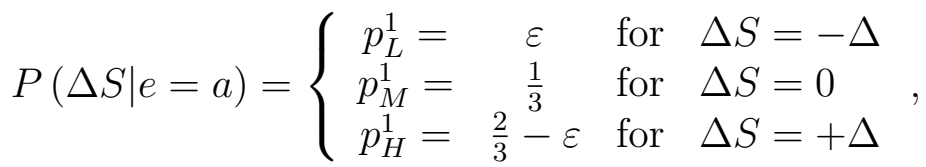

with $\varepsilon<\frac{1}{3}$. We consider two time instants: $t_{0}$ denotes the implementation date of the SOP,$t_{E}$ the instant of exercise given the stock price exceeds the strike price. Without loss of generality define one share to exist in $t_{0}$. Consequently, the initial value of the firm is equal to the current stock price $S_{0} . S_{0}+\Delta S$ represents the value of the firm in $t_{E}$ prior to exercise. Further, we assume that the options granted confirm the right to purchase a multiple $\pi$ of the firm's initial number of shares requiring an outlay of $\pi X$, where $X$ represents the options' strike price. E.g., $\pi=2$ means that twice the number of existing shares is conditionally granted to the manager. The manager's amount of holding after exercise is $\frac{\pi}{1+\pi}$. Legal restrictions limiting the maximal number of options granted are neglected. Moreover, we abstract from any kind of exercise restriction meaning that the strike price $X$ and the number of granted options $\pi$ are the only relevant factors.

\subsection{Benchmark solution: Optimal SOP conditions in a tax-free world}

Given the management's exercise behavior and the share price's reaction on the manager's additional effort, we are able to model explicitly the effects resulting from taxation taking into account dilution effects. In general, strike prices $X<S_{0}-\Delta$ can never be optimal from the shareholder's perspective as they provide counterproductive incentives; the proof is given in appendix B. Further, since the probabilities for $\Delta S=0$ are equal under both 
managerial efforts $\left(p_{M}^{0}=p_{M}^{1}=\frac{1}{3}\right)$, they cancel out, meaning remuneration having the intended incentive effect can only be cost-minimizing iff $X \geq S_{0}$. Using the probability distributions specified above the agency problem without taxes can be formulated as follows. The shareholder's objective function $\Omega$ is defined by:

$$
\Omega(\pi, X)=p_{L}^{1} \cdot(-\Delta)+p_{M}^{1} \cdot 0+p_{H}^{1} \cdot\left[\frac{1}{1+\pi}\left(S_{0}+\Delta+\pi X\right)-S_{0}\right] \rightarrow_{\pi, X} \max
$$

Economically, the shareholder maximizes the expected growth of wealth by optimally choosing $\pi$ and $X$. Since $X \geq S_{0}$, the first two addends in (3) correspond to states with no exercise. These terms are irrelevant for the optimal SOP conditions given a SOP is implemented. Contrary, for a rising firm value, the manager receives newly issued shares. This leads to a dilution effect represented by the fraction $\frac{1}{1+\pi}$. The final wealth of the firm consists of the initial wealth $S_{0}$, the increase in wealth $\Delta$ and the manager's payment of the strike price $\pi X$. As we focus on increments, the initial wealth $S_{0}$ belonging to the initial shareholder only has to be deducted. The modified objective function $\Omega^{\text {mod }}$ is given by:

$$
\Omega^{\bmod }(\pi, X)=p_{H}^{1} \cdot\left[\frac{1}{1+\pi}\left(S_{0}+\Delta+\pi X\right)-S_{0}\right] \rightarrow_{\pi, X} \max
$$

The agent's objective function, called incentive constraint $(I C)$, restricts the shareholder's optimization. The manager maximizes his expected total utility by adjusting his effort, i.e., by choosing from the set of feasible distribution functions:

$$
\begin{aligned}
I C(\pi, X) & =p_{L}^{1} \cdot 0+p_{M}^{1} \cdot 0+p_{H}^{1} \cdot\left[\frac{\pi}{1+\pi}\left(S_{0}+\Delta-X\right)\right]^{\gamma}-V^{a} \\
& \geq p_{L}^{0} \cdot 0+p_{M}^{0} \cdot 0+p_{H}^{0} \cdot\left[\frac{\pi}{1+\pi}\left(S_{0}+\Delta-X\right)\right]^{\gamma} \\
& \Leftrightarrow \frac{\pi}{1+\pi}\left(S_{0}+\Delta-X\right) \geq \underbrace{\left(\frac{V^{a}}{p_{H}^{1}-p_{H}^{0}}\right)^{\frac{1}{\gamma}}}_{\alpha} \\
& \Leftrightarrow X \leq \Delta+S_{0}-\alpha \frac{1+\pi}{\pi}
\end{aligned}
$$

The incentive constraint is a requirement on the SOP conditions. It ensures that the agent will provide additional effort if his expected utility from remuneration, net of the disutility 
of effort, exceeds his expected utility when providing no additional effort. Taking into account $X \geq S_{0}$, from (5) follows that $\Delta \geq \alpha \frac{1+\pi}{\pi}$ must hold. Further, a participation constraint $(P C)$ has to be considered:

$$
P C(\pi, X)=p_{L}^{1} \cdot 0+p_{M}^{1} \cdot \delta+p_{H}^{1} \cdot\left[\frac{\pi}{1+\pi}\left(S_{0}+\Delta-X\right)\right]^{\gamma}-V^{a} \geq 0
$$

It indicates that the agent will participate in the SOP only if it grants a non-negative additional utility. Comparing (5) and (6) shows that the participation constraint is redundant, because the right-hand side of (5) is non-negative. Since the shareholder maximizes his expected growth of wealth, it can never be optimal to reduce the strike price below the critical threshold. Hence, in (5) the strict inequality can be replaced by equality, meaning the optimal strike price is defined as a function of the granted share fraction.

However, with this function only the optimal program conditions are defined given it is advantageous to implement a SOP. In the next step, a condition ensuring the optimality of granting options is derived. This is done by comparing the shareholder's wealth differences resulting from the possible effort levels:

$$
\begin{aligned}
p_{L}^{1} \cdot(-\Delta)+p_{M}^{1} \cdot 0+p_{H}^{1} \cdot\left[\frac{1}{1+\pi}\left(S_{0}+\Delta+\pi X\right)-S_{0}\right] & \geq p_{L}^{0} \cdot(-\Delta)+p_{M}^{0} \cdot 0+p_{H}^{0} \cdot \Delta \\
\Delta & \geq \frac{\frac{2}{3}-\varepsilon}{\frac{2}{3}-2 \varepsilon} \alpha
\end{aligned}
$$

Note that for a high impact of the additional effort $(\varepsilon \rightarrow 0)$, the condition reduces to $\Delta \geq \alpha$, and for a low impact $\left(\varepsilon \rightarrow \frac{1}{3}\right)$, the condition becomes $\Delta \rightarrow \infty$. This means that $\Delta$ has to be sufficiently high to ensure the implementation of a SOP is advantageous for the shareholder. Since the conditions (5) and (7) do not contradict each other, sets of parameters resulting in the optimality of a SOP implementation exist.

Given a SOP is favourable, $X=S_{0}+\Delta-\alpha \frac{1+\pi}{\pi}$ has to be inserted into the shareholder's modified objective function, in order to identify the optimal $(\pi, X)$-combination:

$$
\Omega^{\mathrm{mod}}\left(\pi^{*}\right)=p_{H}^{1} \cdot\left[\frac{1}{1+\pi}\left(S_{0}+\Delta+\pi\left(S_{0}+\Delta-\alpha \frac{1+\pi}{\pi}\right)\right)-S_{0}\right]=p_{H}^{1}(\Delta-\alpha)
$$


Since this expression is independent of $\pi$ every $(\pi, X)$-combination satisfying conditions (5) and (7) is an optimal solution. A prominent case is given by the exercise price $X=S_{0}$, which is commonly used in real-world SOPs. The corresponding optimal share fraction can be derived by solving (5) for $\pi$ :

$$
\pi^{*}\left(S_{0}\right)=\frac{\alpha}{\Delta-\alpha} .
$$

Further, as can be inferred from $\alpha$ every optimal solution is a function of the manager's individual utility function, i.e., his risk aversion $\gamma$ and his effort aversion $V^{a}$, and the probability distribution describing the expected future firm value.

\section{Optimal SOP conditions with taxes}

\subsection{Taxation of managerial remuneration}

Regardless of the preferential treatment of SOPs compared to ordinary salary the remuneration resulting from stock options is subject to tax in most industrialized countries. To focus on the effects of managerial taxation, taxes on the firm as well as on the shareholder level are neglected in this section, meaning the German case is considered here. The manager's exercise gain is taxed with the rate $\tau_{M}$. Neglecting taxation on the other levels, the shareholder's modified objective function formally remains unchanged, compared to the tax-free world and is still given by (4). With the same reasoning as above, $X<S_{0}$ can never be cost-minimizing. Nevertheless, the optimal SOP conditions change, since the manager has to be compensated for the wage tax. This results in the post-tax incentive constraint:

$$
\begin{aligned}
I C\left(\pi, X, \tau_{M}\right) & =p_{L}^{1} \cdot 0+p_{M}^{1} \cdot 0+p_{H}^{1} \cdot\left[\frac{\pi}{1+\pi}\left(1-\tau_{M}\right)\left(S_{0}+\Delta-X\right)\right]^{\gamma}-V^{a} \\
& \geq p_{L}^{0} \cdot 0+p_{M}^{0} \cdot 0+p_{H}^{0} \cdot\left[\frac{\pi}{1+\pi}\left(1-\tau_{M}\right)\left(S_{0}+\Delta-X\right)\right]^{\gamma} \\
& \Leftrightarrow X \leq \Delta+S_{0}-\alpha \frac{1+\pi}{\pi} \frac{1}{1-\tau_{M}}
\end{aligned}
$$

Evidently, the partial derivative of the right-hand side of (10) with respect to $\tau_{M}$ is negative. Hence, an increasing tax rate induces a decreasing strike price holding the 
granted share fraction constant. As in the tax-free case the participation constraint is redundant. Replacing the inequality by equality and inserting (10) into the modified objective function (4) yields:

$$
\Omega^{\bmod }\left(\pi^{*}\right)=p_{H}^{1}\left(\Delta-\frac{\alpha}{1-\tau_{M}}\right)
$$

Again, each $(\pi, X)$-combination satisfying (10) is optimal. For the special case $X=S_{0}$ this leads to the optimal share fraction:

$$
\pi^{*}\left(S_{0}\right)=\frac{\alpha}{\Delta\left(1-\tau_{M}\right)-\alpha}
$$

Comparing (12) with the tax-free case (9) discloses that the optimal share fraction $\pi^{*}$ rises with an increasing managerial tax rate $\tau_{M}$. Economically, the management demands a constant post-tax remuneration for compensating the disutility of effort $V^{a}$ that is an individual constant and herewith unaffected by taxation. The same explanation applies for the decreased strike price given a constant share fraction as revealed in (10).

Apart from the tax impact on the optimal SOP conditions taxation can alter the decision whether to implement a SOP at all. The optimality condition for granting options is derived as in the tax-free case. Due to changes in the SOP conditions it becomes more restrictive:

$$
\begin{aligned}
p_{L}^{1} \cdot(-\Delta)+p_{M}^{1} \cdot 0+p_{H}^{1} \cdot\left[\frac{1}{1+\pi}\left(S_{0}+\Delta+\pi X\right)-S_{0}\right] & \geq p_{L}^{0} \cdot(-\Delta)+p_{M}^{0} \cdot 0+p_{H}^{0} \cdot \Delta \\
\Delta & \geq \frac{\frac{2}{3}-\varepsilon}{\frac{2}{3}-2 \varepsilon} \cdot \frac{\alpha}{1-\tau_{M}}
\end{aligned}
$$

As the taxation on the managerial level raises their costs SOPs will be implemented less frequently. Positive incentive effects are foregiven due to this kind of non-neutral taxation.

\subsection{Deductibility of managerial remuneration at the firm level}

Integrating the firm level into the model specified in the previous section allows to analyse the incentive effects caused by the deductibility of the SOP costs incurred by the dilution effect. This leads to the hypothetical case mentioned in table 2. In contrast to taxation 
solely on the managerial level, deductibility on the corporate level reduces the costs of a SOP. Since marginal tax rates are assumed to fall short of $100 \%$, a positive net contribution by the shareholder to managerial remuneration remains. For this reason, strike prices $X<S_{0}-\Delta$ can never be optimal under deductibility as well. It can be shown that strike prices $X<S_{0}$ can be optimal only in extreme cases (see appendices C and D.2). This section primarily focuses on the typical case $X \geq S_{0}$.

Under this assumption the shareholder's modified objective function is:

$$
\Omega^{\bmod }(\pi, X)=p_{H}^{1} \cdot\left[\frac{1}{1+\pi}\left(S_{0}+\Delta+\pi X\right)-S_{0}+\frac{1}{1+\pi} \tau_{C} \frac{\pi}{1+\pi}\left(\Delta+S_{0}-X\right)\right] \rightarrow_{\pi, X} \max
$$

$\left(\Delta+S_{0}-X\right)$ is the exercise gain realised by the manager weighted with his post-exercise share fraction $\frac{\pi}{1+\pi}$. This gives the total remuneration costs. Multiplying with the corporate tax rate $\tau_{C}$ yields the total tax shield on managerial remuneration. Since the manager, now being shareholder as well, participates in the tax reimbursement, the fraction belonging to the original shareholder has to be separated by multiplying with the fraction $\frac{1}{1+\pi}$. Accordingly, the incentive constraint becomes:

$$
\begin{aligned}
I C(\pi, X) & =p_{L}^{1} \cdot 0+p_{M}^{1} \cdot \delta+p_{H}^{1} \cdot\left[\frac{\pi}{1+\pi}\left(1-\tau_{M}+\frac{\pi}{1+\pi} \tau_{C}\right)\left(S_{0}+\Delta-X\right)\right]^{\gamma}-V^{a} \\
& \geq p_{L}^{0} \cdot 0+p_{M}^{0} \cdot \delta+p_{H}^{0} \cdot\left[\frac{\pi}{1+\pi}\left(1-\tau_{M}+\frac{\pi}{1+\pi} \tau_{C}\right)\left(S_{0}+\Delta-X\right)\right]^{\gamma} \\
& \Leftrightarrow X \leq \Delta+S_{0}-\alpha \frac{1+\pi}{\pi} \frac{1}{1-\tau_{M}+\frac{\pi}{1+\pi} \tau_{C}}
\end{aligned}
$$

$\delta$ represents the total utility the agent receives given the firm's wealth position remains unchanged. As it cancels out, it can be disregarded here. Using the same arguments as above, for optimality (15) has to hold with equality. Dropping the inequality sign and inserting (15) into the modified objective function (14) yields:

$$
\Omega^{\mathrm{mod}}(\pi)=p_{H}^{1} \cdot\left[\Delta-\frac{\alpha\left(1+\pi-\tau_{C}\right)}{(1+\pi)\left(1-\tau_{M}+\frac{\pi}{1+\pi} \tau_{C}\right)}\right]
$$

Comparing (16) with the modified objective functions (8) and (11), it emerges for the first time that the shareholder's objective function depends on the option conditions since the 
fraction of granted shares $\pi$ appears in (16). Hence, the shareholder is no longer indifferent between arbitrarily chosen combinations of $X$ and $\pi$ satisfying the incentive constraint (15) with equality. This phenomenon is caused by the possibility for tax arbitrage: for $\tau_{C}>\tau_{M}$, the tax shield on the corporate level exceeds the manager's tax payment.

In order to derive the optimal share fraction $\pi$ the derivative of the modified objective function (14) with respect to $\pi$ is computed:

$$
\frac{\mathrm{d} \Omega^{\bmod }(\pi)}{\mathrm{d} \pi}=-p_{H}^{1}\left[\frac{\alpha \tau_{C}\left(\tau_{C}-\tau_{M}\right)}{\left(1+\pi\left(1+\tau_{C}\right)-(1+\pi) \tau_{M}\right)^{2}}\right] \gtreqless 0 \Leftrightarrow \tau_{M} \gtreqless \tau_{C}
$$

Depending on the difference of the tax rates on the corporate and the managerial level three cases have to be distinguished:

1. $\tau_{M}=\tau_{C}$ : If the tax rates are identical, the tax payment on the manager's level and the tax shield on the corporate level cancel out leading to the benchmark solution (8): $\Omega^{\text {mod }}=p_{H}^{1} \cdot(\Delta-\alpha)$. From a comparison of (15) with the tax-free case (5) follows that identical managerial and corporate tax rates induce a lower strike price, given a constant fraction $\pi$. Accordingly, for a given strike price the fraction of granted options increases compared to the tax-free case. The resulting strike price is calculated in a way that the corresponding tax shield exactly offsets the higher gross managerial remuneration necessary to compensate for his tax burden. Despite the impact of taxation on the optimal SOP parameters, the identity of tax rates on the corporate and the managerial level implies neutrality of taxation with respect to the decision to implement a SOP.

2. $\tau_{M}>\tau_{C}$ : Since it is more costly to compensate the manager by options than via the participation in the tax reimbursement, which is not subject to the manager's individual tax rate, the shareholder tends to maximize the fraction of this preferentially treated compensation component. From (17) it follows that $\pi$ should be chosen infinitely high, which means that the shareholder gives an option to acquire 
the entire firm. The corresponding strike price approaches:

$$
\left.X\right|_{\tau_{M}>\tau_{C}}=\lim _{\pi \rightarrow \infty}\left(\Delta+S_{0}-\alpha \frac{1+\pi}{\pi} \frac{1}{1-\tau_{M}+\frac{\pi}{1+\pi} \tau_{C}}\right)=\Delta+S_{0}-\frac{\alpha}{1-\tau_{M}+\tau_{C}}
$$

3. $\tau_{M}<\tau_{C}$ : From the negativity of the derivative (17) it follows that from the set of feasible $\pi$-X-combinations the one with the smallest $\pi$ is chosen given it is optimal to exclude strike prices below $S_{0}$. Consequently, the resulting strike price is $X=$ $S_{0}$. The corresponding share fraction is given by the positive root of a quadratic equation:

$$
\begin{aligned}
\left.\pi\right|_{X=S_{0}}= & -\frac{\Delta\left(1-\tau_{M}\right)-2 \alpha}{2\left(\Delta\left(1-\tau_{M}+\tau_{C}\right)-\alpha\right)} \\
& +\sqrt{\left(\frac{\Delta\left(1-\tau_{M}\right)-2 \alpha}{2\left(\Delta\left(1-\tau_{M}+\tau_{C}\right)-\alpha\right)}\right)^{2}+\frac{\alpha}{\left(1-\tau_{M}+\tau_{C}\right) \Delta-\alpha}}
\end{aligned}
$$

Economically, this result can be explained by the fact that the manager participates in the tax reimbursement after exercise, which can be seen from (15). In contrast to the preceeding case, remuneration in options is now less costly than letting the manager participate in the tax reimbursement. Consequently, the shareholder minimizes the fraction of the tax shield given to the manager. In effect, the part of the tax reimbursement attributable to the manager serves as a substitute for remuneration, meaning a higher exercise price $X$ for a given fraction $\pi$ compared to the tax-free case can be set.

In contrast to the preceeding sections it can be shown that due to tax arbitrage strike prices below $S_{0}$ can be optimal in extreme cases $\left(\tau_{C} \gg \tau_{M}\right)$. An example is provided in appendix D.2. Some legislations, e.g. Italy, exclude preferential taxation for strike prices below $S_{0}$. Interestingly, this may lead to contrarian effects as taxation favours lower strike prices in the present case. 
The decision to implement a SOP can be heavily distorted by taxation, too. Excluding strike prices $X<S_{0}$ the implementation condition can be written as:

$$
\begin{aligned}
& p_{L}^{1} \cdot(-\Delta)+p_{M}^{1} \cdot 0+p_{H}^{1} \cdot\left[\frac{1}{1+\pi}\left(S_{0}+\Delta+\pi X\right)-S_{0}+\frac{1}{1+\pi} \tau_{C} \frac{\pi}{1+\pi}\left(\Delta+S_{0}-X\right)\right] \\
\geq & p_{L}^{0} \cdot(-\Delta)+p_{M}^{0} \cdot 0+p_{H}^{0} \cdot \Delta
\end{aligned}
$$

Substitution of $X=\Delta+S_{0}-\alpha \frac{1+\pi}{\pi} \frac{1}{1-\tau_{M}+\frac{\pi}{1+\pi} \tau_{C}}$ and further transformations yield:

$$
\Delta \geq \frac{\frac{2}{3}-\varepsilon}{\frac{2}{3}-2 \varepsilon} \cdot \alpha \cdot \frac{1+\pi-\tau_{C}}{1-\tau_{M}+\pi\left(1+\tau_{C}-\tau_{M}\right)}
$$

with

$$
\frac{1+\pi-\tau_{C}}{1-\tau_{M}+\pi\left(1+\tau_{C}-\tau_{M}\right)} \gtreqless 1 \Leftrightarrow \tau_{M} \gtreqless \tau_{C}
$$

Only in the first case $\left(\tau_{C}=\tau_{M}\right)$ taxation is neutral with respect to the decision to implement a SOP. In contrast, in the second case $\left(\tau_{M}>\tau_{C}\right)$ SOPs will be implemented less frequently than in the tax-free case because the negative effect caused by managerial taxation dominates the positive effect of the tax reimbursement. In the third case $\left(\tau_{C}>\right.$ $\tau_{M}$ ), taxation might induce the implementation of SOPs that would not be advantageous for the shareholder in the tax-free case.

\subsection{Capital Gains Taxation}

Capital gains realized by the shareholder are subject to -possibly preferential- taxation in several countries. In this section, it is assumed that the shareholder sells his shares immediately after the end of the SOP. Assuming the shareholder acquired his shares in $t_{0}$, $S_{0}$ serves as the initial costs for calculating the capital gain. Depending on the terminal value of the firm a positive or negative tax base may result. Positive capital gains are taxed at the rate $\tau_{G}$, capital losses at the rate $\tau_{L}$. Asymmetric treatment of capital gains and losses $\left(\tau_{G}>\tau_{L}\right)$ may be induced by an incomplete loss-offset observable under most legislations. A further distinction arises with respect to deductibility of SOP costs as discussed in the previous section. With $\tau_{C}>0$, the U.S. case is considered, wheras $\tau_{C}=0$ represents the U.K. case. 
From the manager's perspective, the sales revenue coincides with the initial costs given by the share price at date $t_{E}$ resulting in a zero capital gains tax base. ${ }^{3}$ Hence, the incentive constraint (15) and the (redundant) participation constraint remain unchanged. In contrast, the shareholder's objective function relevant for optimization purposes changes to:

$$
\begin{aligned}
& \Omega(\pi, X)=p_{L}^{1} \cdot(-\Delta) \cdot\left(1-\tau_{L}\right)+p_{M}^{1} \cdot 0 \\
& +p_{H}^{1} \cdot\left(1-\tau_{G}\right) \cdot\left[\frac{1}{1+\pi}\left(S_{0}+\Delta+\pi X\right)-S_{0}+\frac{1}{1+\pi} \tau_{C} \frac{\pi}{1+\pi}\left(\Delta+S_{0}-X\right)\right] \rightarrow_{\pi, X} \max
\end{aligned}
$$

In the downward state, no options are exercised and the manager does not participate in the resulting capital loss of $\Delta$. In the constant state, neither an exercise nor a capital gain occur. In the upward state, the shareholder realizes a capital gain given by the modified objective function (14).

Assuming symmetric capital gains taxation $\left(\tau_{G}=\tau_{L}\right)$ the objective function (23) corresponds to the non-modifed objective function from section 4.2 , multiplied by the constant $\left(1-\tau_{G}\right)$. In this case, neither the optimal SOP conditions nor the optimality of implementing an SOP change.

Because of the unchanged incentive constraint asymmetric capital gains taxation $\left(\tau_{G}>\tau_{L}\right)$ does not have an impact on the optimal SOP conditions as well if the extreme case $\left(\tau_{C} \gg \tau_{M}\right)$ identified in section 4.2 is neglected. However, the decision to implement the SOP is distorted because the shareholder's costs and benefits are affected asymmetrically. Without an SOP, the importance of the downward state increases because the tax reimbursement falls short of the tax payment in the upward state. Hence, avoiding the downward state is advantageous to the shareholder, meaning that SOPs are implemented more frequently compared to the pre-tax case. 


\section{Conclusion}

We analyzed the impact of different tax regimes on the implementation decision and the design of SOPs. Under taxation of managerial remuneration only, the manager demands a higher gross income and SOPs become more expensive. This leads to the conclusion that SOPs which are advantageous in the pre-tax case are possibly not realized in the presence of taxation. This effect might be offset by deductibility of SOP costs on the corporate level. Depending on the ratio of the tax rates $\tau_{M}$ and $\tau_{C}$ very high or very low strike prices may be optimal illustrating that this case is very sensitive to variations of tax parameters. Integrating symmetric capital gains taxation, neither the optimality nor the optimal conditions of a SOP are altered. In contrast, asymmetric capital gains taxation favours the implementation of SOPs while leaving their optimal conditions unchanged.

These results have implications for fiscal as well as entrepreneurial decisions. From a tax policy perspective, changing a single tax parameter requires taking into account the interdependencies between different levels of taxation. Deviations from neutral taxation may induce welfare losses. From an entrepreneurial perspective, SOP conditions approved under a particular legislation should not simply be transferred. Rather, a comprehensive analysis of the host country's tax system is indispensable. As a result, neglecting taxation may induce wrong decisions and a waste of funds.

\section{Appendix}

\section{A Tax legislation on SOPs}

Because one important factor in our analysis is the taxation on the management level, which varies over different countries, we provide a survey of the taxation of stock options in the following table 3 mainly based on Towers Perrin (2001) and Müssener and Prahs (2000). Additional references are given in the column 'notes'. 


\section{Table 3}

Taxation of stock options in various countries

\begin{tabular}{|c|c|c|c|c|c|}
\hline country & $\begin{array}{l}\text { instant of } \\
\text { taxation }\end{array}$ & tax base & $\begin{array}{l}\text { capital } \\
\text { gains } \\
\text { taxation? }\end{array}$ & $\begin{array}{l}\text { tax- } \\
\text { favoured } \\
\text { SOP? }\end{array}$ & notes \\
\hline Australia & $t_{E}$ & & yes & yes & \\
\hline Austria & $t_{E}$ & hybrid & no & & $\begin{array}{l}\text { part of the exercise gain is cal- } \\
\text { culated as if an up-front tax- } \\
\text { ation would take place (see } \\
\text { Knoll, 2002) }\end{array}$ \\
\hline Belgium & $t_{0}$ & $0.15 \cdot S_{0}$ & no & & $\begin{array}{l}\text { reduction of the tax base to } \\
0.075 \cdot S_{0} \text { under certain condi- } \\
\text { tions possible (see Bartholmé } \\
\text { and Strickx, 1999; Bernhardt, } \\
2001 \text { ) }\end{array}$ \\
\hline Brazil & $t_{S}$ & & yes & yes & \\
\hline Canada & $t_{E}$ & $S_{E}-X$ & yes & yes & \\
\hline France & $t_{S}$ & $\begin{array}{l}\left(S_{S}-S_{E}\right)+ \\
\left(S_{E}-X\right)\end{array}$ & yes & yes & $\begin{array}{l}\text { profit in the first parantheses } \\
\text { is taxed regularly, the differ- } \\
\text { ence in second parantheses is } \\
\text { taxed preferentially (see Gin- } \\
\text { ter and Deis, 2001) }\end{array}$ \\
\hline Germany & $t_{E}$ & $S_{E}-X$ & no & no & $\begin{array}{l}\text { (see Guenkel and Hagen, } \\
2002)\end{array}$ \\
\hline Italy & $t_{E}$ & $S_{E}-X$ & yes & no & $\begin{array}{l}\text { taxation in } t_{E} \text { only if } X<S_{0} \\
\text { (see Serbini, 2000) }\end{array}$ \\
\hline Japan & $t_{E}$ & $S_{E}-X$ & yes & yes & (see Katsushima, 1997) \\
\hline Netherlands & $t_{0}$ & $\begin{array}{l}\text { legally de- } \\
\text { fined option } \\
\text { value }\end{array}$ & no & yes & $\begin{array}{l}\text { taxation of capital gains if op- } \\
\text { tion is exercised within three } \\
\text { years }\end{array}$ \\
\hline Switzerland & $t_{0}$ & $\begin{array}{l}\text { adjusted } \\
\text { Black- } \\
\text { Scholes } \\
\text { option } \\
\text { value } \\
\end{array}$ & no & yes & $\begin{array}{l}\text { (see Knoll, 2002) options with } \\
\text { terms longer than } 10 \text { years are } \\
\text { taxed in } t_{E}\end{array}$ \\
\hline U.K. & $t_{E}$ & $S_{E}-X$ & yes & yes & \\
\hline U.S. & $t_{E}$ & $S_{E}-X$ & yes & yes & (see Phillips et al., 2002) \\
\hline
\end{tabular}




\section{B Maximum number of strike prices}

Lemma: For any given $\pi$ there are at most two strike prices $X$ that solve the incentive constraint with equality.

Proof: Not excluding strike prices $X<S_{0}-\Delta$ the incentive constraint would be given by:

$$
\begin{gathered}
I C(\pi, X)=p_{L}^{1} \cdot\left[\max \left\{\frac{\pi}{1+\pi}\left(S_{0}-\Delta-X\right) ; 0\right\}\right]^{\gamma}+p_{M}^{1} \cdot \delta+p_{H}^{1} \cdot\left[\frac{\pi}{1+\pi}\left(S_{0}+\Delta-X\right)\right]^{\gamma}-V^{a} \\
\geq p_{L}^{0} \cdot\left[\max \left\{\frac{\pi}{1+\pi}\left(S_{0}-\Delta-X\right) ; 0\right\}\right]^{\gamma}+p_{M}^{0} \cdot \delta+p_{H}^{0} \cdot\left[\frac{\pi}{1+\pi}\left(S_{0}+\Delta-X\right)\right]^{\gamma} \\
\Leftrightarrow \underbrace{\left(p_{H}^{1}-p_{H}^{0}\right) \cdot\left[\frac{\pi}{1+\pi}\left(S_{0}+\Delta-X\right)\right]^{\gamma}-\left(p_{L}^{0}-p_{L}^{1}\right) \cdot\left[\max \left\{\frac{\pi}{1+\pi}\left(S_{0}-\Delta-X\right) ; 0\right\}\right]^{\gamma} \geq V^{a}}_{f(X)}
\end{gathered}
$$

Obviously,

$$
\lim _{X \uparrow S_{0}-\Delta} f(X)=\lim _{X \downarrow S_{0}-\Delta} f(X)
$$

Further, the derivative $\frac{\mathrm{d} f(X)}{\mathrm{d} X}$ is positive for $0<X<S_{0}-\Delta$ :

$$
\frac{\mathrm{d} f(X)}{\mathrm{d} X}=-\gamma\left(\frac{1}{3}-\varepsilon\right)\left(\frac{\pi}{1+\pi}\right)\left\{\left[\frac{\pi}{1+\pi}\left(S_{0}+\Delta-X\right)\right]^{\gamma-1}-\left[\frac{\pi}{1+\pi}\left(S_{0}-\Delta-X\right)\right]^{\gamma-1}\right\}>0
$$

Since $\gamma<1$, the second term in braces exceeds the first one. Hence, the derivative is positive. For $X \geq S_{0}-\Delta$, the opposite holds:

$$
\frac{\mathrm{d} f(X)}{\mathrm{d} X}=-\gamma\left(\frac{1}{3}-\varepsilon\right)\left(\frac{\pi}{1+\pi}\right)\left[\frac{\pi}{1+\pi}\left(S_{0}+\Delta-X\right)\right]^{\gamma-1}<0
$$

Thus, there are at most two $X^{=}$solving (24) with equality. If no $X$ satisfies (24) with equality for a given $\pi$ the SOP is not feasible. If there is only one solution for the optimal strike price, $X^{*} \geq S_{0}-\Delta$ holds (see figure). For two $X^{=}$in the relevant interval the strike price $X \geq S_{0}-\Delta$ is optimal from the shareholder's point of view. This corresponds to economic intuition because for a given $\pi$ a higher strike price induces a lower probability for exercise combined with a smaller dilution effect. 
Figure 2

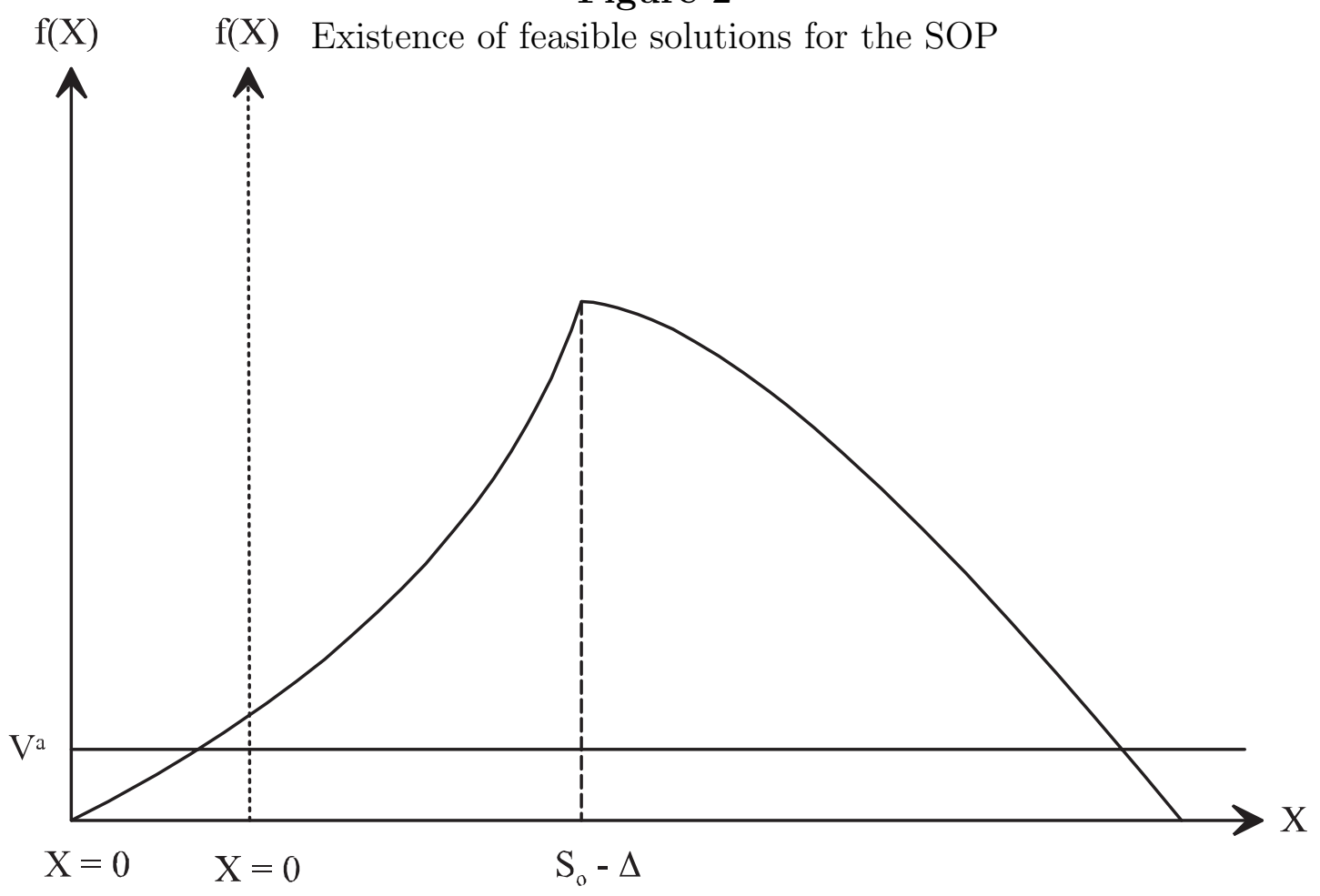

In case I (solid ordinate), there are two intersections of $f(x)$ and $V^{a}$ in the relevant interval $] 0, \infty[$, meaning that two positive strike prices satisfy the incentive constraint. Of course, the shareholder chooses the greater one, leading to a higher profit. In case II (dashed ordinate), only one feasible solution exists. Due to the function's curvature this solution must be positive.

\section{A lower bound for strike prices}

Lemma: From the shareholder's perspective, strike prices $S_{0}-\Delta \leq X<S_{0}$ can only be optimal for $\tau_{C}>\tau_{M}$.

Proof: Given a strike price $X \geq S_{0}-\Delta$ the shareholder's modified objective function is given by:

$$
\begin{aligned}
\Omega^{\mathrm{mod}}= & p_{M}^{1} \cdot\left[\frac{1}{1+\pi}\left(S_{0}+\pi X\right)-S_{0}+\frac{1}{1+\pi} \tau_{C} \frac{\pi}{1+\pi}\left(S_{0}-X\right)\right] \\
& +p_{H}^{1} \cdot\left[\frac{1}{1+\pi}\left(S_{0}+\Delta+\pi X\right)-S_{0}+\frac{1}{1+\pi} \tau_{C} \frac{\pi}{1+\pi}\left(\Delta+S_{0}-X\right)\right]
\end{aligned}
$$

Inserting the strike price from the incentive constraint (15) and deriving (28) with respect 
to $\pi$ yields:

$$
\frac{\mathrm{d} \Omega^{\mathrm{mod}}}{\mathrm{d} \pi}= \begin{cases}-p_{H}^{1}\left[\frac{\alpha \tau_{C}\left(\tau_{C}-\tau_{M}\right)}{\left(1+\pi\left(1+\tau_{C}\right)-(1+\pi) \tau_{M}\right)^{2}}\right] & \text { for } X \geq S_{0} \\ p_{M}^{1}\left[\frac{\Delta\left(1+\pi-(1-\pi) \tau_{C}\right)}{(1+\pi)^{3}}\right]-\left(p_{H}^{1}+p_{M}^{1}\right)\left[\frac{\alpha \tau_{C}\left(\tau_{C}-\tau_{M}\right)}{\left(1+\pi\left(1+\tau_{C}\right)-(1+\pi) \tau_{M}\right)^{2}}\right] & \text { for } S_{0}-\Delta<X<S_{0}\end{cases}
$$

Obviously, the last derivative can only be negative for $\tau_{C}>\tau_{M}$.

\section{Numerical Examples}

The following numerical examples illustrate the impact of the different tax regimes described in the preceeding sections. The parameters common for all examples are:

\section{Table 4}

General parameters for the numerical examples

\begin{tabular}{l|ll} 
parameter & variable & value \\
\hline probability distribution without additional managerial effort & $p_{L}^{0}=p_{M}^{0}=p_{H}^{0}$ & $\frac{1}{3}$ \\
downward probability with additional effort & $p_{L}^{1}=\varepsilon$ & $\frac{1}{10}$ \\
constant-state probability with additional effort & $p_{M}^{1}$ & $\frac{1}{3}$ \\
upward probability with additional effort & $p_{H}^{1}=\frac{2}{3}-\varepsilon$ & $\frac{17}{30}$ \\
initial share price & $S_{0}$ & 100 \\
possible change of the firm value & $\Delta$ & 10 \\
disutility of effort & $V^{a}$ & $\frac{1}{5}$ \\
risk aversion parameter & $\gamma$ & $\frac{1}{2}$
\end{tabular}

\section{D.1 Taxation of managerial remuneration}

The pre-tax case $\left(\tau_{M}=0\right)$ is compared with the case of taxation on the managerial level for $\tau_{M}=0.5, \tau_{M}=0.91$, and $\tau_{M}=0.92$.

\section{Table 5}

SOP conditions for different managerial tax rates

\begin{tabular}{l|llll}
$\tau_{M}$ & 0 & 0.5 & 0.91 & 0.92 \\
\hline$X$ & 100 & 100 & 100 & $(100)$ \\
$\pi(X)$ & 0.079 & 0.172 & 4.444 & $(11.250)$ \\
shareholder's benefit from SOP & 4.250 & 3.834 & 0.041 & $(-0.537)$ \\
manager's net benefit from SOP & 0.286 & 0.286 & 0.286 & $(0.286)$
\end{tabular}


For $\tau_{M}=0.5$, a SOP is implemented. $\pi=0.172$ means that the manager holds a post-exercise fraction of the firm of $\frac{\pi}{1+\pi}=14.68 \%$. For a tax rate between $91 \%$ and $92 \%$ the decision to implement changes. Whereas a SOP would be advantageous for the shareholder given a managerial tax rate of $91 \%$, it becomes harmful for $\tau_{M}=92 \%$. The parentheses in the last column indicate that the parameters are hypothetical as the SOP is not realized. Note that the critical tax rate depends on $\Delta$. Changing the example's global variable, e.g., for $\Delta=2$, the critical tax rate is $\tau_{M}=55.4 \%$.

\section{D.2 Deductibility of managerial remuneration at the firm level}

Holding $\tau_{M}=0.5$ constant, the corporate tax rate is set to $\tau_{C}=0.25, \tau_{C}=0.5, \tau_{C}=0.6$, and $\tau_{C}=0.99$ :

\section{Table 6}

Optimal SOP conditions for different corporate tax rates

\begin{tabular}{l|lllll}
$\tau_{C}$ & 0 & 0.25 & 0.5 & 0.6 & 0.99 \\
\hline$X$ & 100 & 109.02 & 100 & 100 & 90 \\
$\pi(X)$ & 0.172 & $\rightarrow \infty$ & 0.149 & 0.146 & 0.070 \\
shareholder's benefit from SOP & 3.834 & 4.112 & 4.250 & 4.322 & 4.596 \\
manager's net benefit from SOP & 0.286 & 0.286 & 0.286 & 0.286 & 0.286
\end{tabular}

For $\tau_{C}<\tau_{M}$, the strike price is chosen as high as possible in connection with $\pi \rightarrow \infty$. This means the entire firm is sold to the manager as expensive as possible. For $\tau_{C}=\tau_{M}$, the pre-tax case emerges. For $\tau_{C}>\tau_{M}$, there is at least one critical $\tau_{C}$ where strike prices $X<S_{0}$ become optimal. The tax shield increasing in $\tau_{C}$ explains the increase in the shareholder's benefit.

\section{D.3 Capital Gains Taxation}

For symmetric capital gains taxation $\left(\tau_{G}=\tau_{L}\right)$, an example is omitted since there are no effects that could be demonstrated. For the case of asymmetric capital gains taxation, the managerial and corporate tax are neglected $\left(\tau_{M}=\tau_{C}=0\right)$. The capital gains tax 
rates are $\tau_{G}=0.5$ and $\tau_{L}=0.2$. Further, $\Delta=0.8$ is set in order to demonstrate a change in the implementation decision. In contrast to the pre-tax case, under a capital gains tax, a SOP is advantageous.

\section{Table 7}

SOP conditions under asymmetric capital gains taxation

\begin{tabular}{l|ll} 
& pre-tax case & capital gains tax \\
\hline$X$ & $(100)$ & 100 \\
$\pi(X)$ & $(11.25)$ & 11.25 \\
shareholder's benefit from SOP & -0.043 & -0.045 \\
shareholder's benefit without SOP & 0 & -0.08
\end{tabular}

Although the shareholder's benefit from the SOP is negative under a capital gains tax, it would be realized because the alternative is even worse.

\section{Notes}

${ }^{1}$ For an overview over the different types of manager-shareholder conflicts refer to Byrd et al. (1998, p. 15). For mechanims mitigating these conflicts see Byrd et al. (1998, p. 18) or Agrawal and Knoeber (1996).

${ }^{2}$ The difference in the assumptions on the parties' attitudes towards risk can be justified as follows: Shareholders can diversify their portfolio and restrict their risk-taking to the unsystematic risk, whereas this is not feasible for managers, see Rajgopal and Shevlin (2002, p. 146) and the references cited there. Note that a power utility function represents a decreasing absolute and a constant relative risk aversion, see Kreps (1988, pp. 74) for the terminology. For an application of the power utility function in the context of stock options, see Huddart (1994).

${ }^{3}$ The initial costs for tax purposes can vary under different legislations. The prominent alternatives are the strike price or the share price at the date of exercise. 


\section{References}

Aboody, D. (1996), 'Market valuation of employee stock options', Journal of Accounting and Economics, Vol. 22, pp. 357-391.

Agrawal, A. and C.R. Knoeber (1996), 'Firm performance and mechanisms to control agency problems between managers and shareholders', Journal of Financial and Quantitative Analysis, Vol. 31, pp. 377-397.

Baber, W.R., S.N. Janakiraman and S.-H. Kang (1996), 'Investment opportunities and the structure of executive compensation', Journal of Accounting and Economics, Vol. 21, pp. 297-318.

Bartholmé, Y. and W. Strickx (1999), 'The new tax regime for stock options in Belgium', Benefits \& Compensation International, Vol. 29, pp. 33-35.

Bernhardt, W. (2001), 'Stock Options - Modalitäten der Besteuerung, Bewertung und Offenlegung im internationalen Kontext', FinanzBetrieb, Vol. 3, pp. 427-433.

— (1999), 'Stock options for or against shareholder value? - New compensation plans for top management and the interests of the shareholders', Corporate Governance, Vol. 7, pp. 123-135.

Bizjak, J.M., J.A. Brickley and J. Coles (1993), 'Stock-based incentive compensation and investment behavior', Journal of Accounting and Economics, Vol. 16, pp. 349-372.

Brickley, J.A., S. Bhagat and R.C. Lease (1985), 'The impact of long-range managerial compensation plans on shareholder wealth', Journal of Accounting and Economics, Vol. 7, pp. 115-129.

Byrd, J., R. Parrino and G. Pritsch (1998), 'Stockholder-manager conflicts and firm value', Financial Analysts Journal, Vol. 54, pp. 14-30. 
Collins, C.M., D.W. Blackwell and J.F. Sinkley (1995), 'The relationship between corporate compensation policies and investment opportunities: Empirical evidence for large bank holding companies', Financial Management, Vol. 24, No. 3, pp. 40-53.

DeFusco, R.A., R.R. Johnson and T.A. Zorn (1990), 'The effect of executive stock option plans on stockholders and bondholders', Journal of Finance, Vol. 45, pp. 617-627.

Ferris, S.P., R. Kumar, R. Sant and P.R. Sopariwala (1998), 'An agency analysis of the effect of long-term performance plans on managerial decision making', Quarterly Review of Economics and Finance, Vol. 38, pp. 73-91.

Gaver, J.J. and K.M. Gaver (1995), 'Compensation policy and the investment opportunity set', Financial Management, Vol. 24, No. 1, pp. 19-32.

Gaver, J.J., K.M. Gaver and G.P. Battistel (1992), 'The stock market reaction to performance plan adoptions', Accounting Review, Vol. 67, pp. 172-182.

Ginter, E. and L. Deis (2001), 'France - New legislation on stock options', European Taxation, Vol. 41, pp. 345-346.

Guenkel, M. and C. Hagen (2002), 'The taxation of stock options in Germany in the light of the new jurisdiction of the Federal Tax Supreme Court', Intertax, Vol. 30, pp. 101-106.

Hall, B.J. (1999), 'The design of multi-year stock option plans', Journal of Applied Corporate Finance, Vol. 12, pp. 97-106.

Hite, G.L. and M.S. Long (1982), 'Taxes and executive stock options', Journal of Accounting and Economics, Vol. 4, pp. 3-14.

Huddart, S. (1994), 'Employee stock options', Journal of Accounting and Economics, Vol. 18, pp. 207-231. 
Katsushima, T. (1997), 'Japanese taxation of stock options: Enactment of US-type ISO encouraged', Intertax, Vol. 25, p. 366.

Knoll, L. (2002), 'Arbeitnehmerseitige Besteuerung von Stock Options im deutschsprachigen Raum', Internationales Steuerrecht, Vol. 11, pp. 325-329.

Kreps, D.M. (1988), Notes on the theory of choice (Westview Press).

Kulatilaka, N. and A.J. Marcus (1994), 'Valuing employee stock options', Financial Analysts Journal, Vol. 50, pp. 46-56.

Kumar, R. and P.R. Sopariwala (1992), 'The effect of adoption of long-term-performance plans on stock prices and accounting numbers', Journal of Financial and Quantitative Analysis, Vol. 27, pp. 561-573.

Larcker, D. (1983), 'The association between performance plan adoption and corporate capital investment', Journal of Accounting and Economics, Vol. 5, pp. 3-30.

Long, M.S. (1992), 'The incentives behind the adoption of executive stock option plans in U.S. corporations', Financial Management, Vol. 21, No. 3, pp. 12-21.

Matsunaga, S.R. (1995), 'The effect of financial reporting costs on the use of employee stock options', Accounting Review, Vol. 70, pp. 1-26.

Müssener, I. and H. Prahs (2000), 'Die Besteuerung von Aktienoptionen im internationalen Vergleich' in Bundesministerium der Finanzen (ed.), www.bundesfinanzministerium.de.

Phillips, L.C., P. Munter and T.R. Robinson (2002), 'Employee stock option plans tax planning considerations', The Ohio CPA Journal, Vol. 61, pp. 12-17.

Rajgopal, S. and T. Shevlin (2002), 'Empirical evidence on the relation between stock option compensation and risk-taking', Journal of Accounting and Economics, Vol. 33, pp. 145-171. 
Serbini, S. (2000), 'The new Italian tax regime applicable to stock option transactions', Intertax, Vol. 28, pp. 211-213.

Smith, C.W. jr. and R.L. Watts (1992), 'The investment opportunity set and corporate financing, dividend, and compensation policies', Journal of Financial Economics, Vol. 32, pp. 263-292.

— (1982), 'Incentive and tax effects of executive compensation plans', Australian Journal of Management, Vol. 7, pp. 139-157.

Towers Perrin (ed.) (2001), Stock options around the world, www.towersperrin.com.

Yermack, D. (1995), 'Do corporations award CEO stock options effectively?', Journal of Financial Economics, Vol. 39, pp. 237-269. 


\section{CESifo Working Paper Series}

(for full list see www.cesifo.de)

749 Hans Gersbach, Democratic Mechanisms: Double Majority Rules and Flexible Agenda Costs, July 2002

750 Bruno S. Frey and Stephan Meier, Pro-Social Behavior, Reciprocity or Both?, July 2002

751 Jonas Agell and Helge Bennmarker, Wage Policy and Endogenous Wage Rigidity: A Representative View From the Inside, July 2002

752 Edward Castronova, On Virtual Economies, July 2002

753 Rebecca M. Blank, U.S. Welfare Reform: What's Relevant for Europe?, July 2002

754 Ruslan Lukach and Joseph Plasmans, Measuring Knowledge Spillovers Using Patent Citations: Evidence from the Belgian Firm's Data, July 2002

755 Aaron Tornell and Frank Westermann, Boom-Bust Cycles in Middle Income Countries: Facts and Explanation, July 2002

756 Jan K. Brueckner, Internalization of Airport Congestion: A Network Analysis, July 2002

757 Lawrence M. Kahn, The Impact of Wage-Setting Institutions on the Incidence of Public Employment in the OECD: 1960-98, July 2002

758 Sijbren Cnossen, Tax Policy in the European Union, August 2002

759 Chandima Mendis, External Shocks and Banking Crises in Developing Countries: Does the Exchange Rate Regime Matter?, August 2002

760 Bruno S. Frey and Lars P. Feld, Deterrence and Morale in Taxation: An Empirical Analysis, August 2002

761 Lars Calmfors and Åsa Johansson, Nominal Wage Flexibility, Wage Indexation and Monetary Union, August 2002

762 Alexander R. W. Robson and Stergios Skaperdas, Costly Enforcement of Property Rights and the Coase Theorem, August 2002

763 Horst Raff, Preferential Trade Agreements and Tax Competition for Foreign Direct Investment, August 2002

764 Alex Cukierman and V. Anton Muscatelli, Do Central Banks have Precautionary Demands for Expansions and for Price Stability? - Theory and Evidence, August 2002

765 Giovanni Peri, Knowledge Flows and Knowledge Externalities, August 2002

766 Daniel Friedman and Nirvikar Singh, Equilibrium Vengeance, August 2002 
767 Sam Bucovetsky and Michael Smart, The Efficiency Consequences of Local Revenue Equalization: Tax Competition and Tax Distortions, August 2002

768 Tapio Palokangas, International Labour Market Regulation and Economic Growth with Creative Destruction, August 2002

769 Rudi Dornbusch, The New International Architecture, September 2002

770 Hans-Werner Sinn, Weber's Law and the Biological Evolution of Risk Preferences: The Selective Dominance of the Logarithmic Utility Function, September 2002

771 Thomas Mayer, The Macroeconomic Loss Function: A Critical Note, September 2002

772 Seppo Honkapohja and Kaushik Mitra, Learning Stability in Economies with Heterogenous Agents, September 2002

773 David Laidler, Inflation Targets Versus International Monetary Integration - A Canadian Perspective, September 2002

774 Morten I. Lau, Panu Poutvaara, and Andreas Wagener, The Dynamic Cost of the Draft, September 2002

775 Steven Brakman, Harry Garretsen, and Charles van Marrewijk, Locational Competition and Agglomeration: The Role of Government Spending, September 2002

776 Anke S. Kessler and Christoph Lülfesmann, The Theory of Human Capital Revisited: On the Interaction of General and Specific Investments, September 2002

777 Kjell Erik Lommerud, Frode Meland and Lars Sørgard, Unionized Oligopoly, Trade Liberalization and Location Choice, September 2002

778 Antonio Merlo and François Ortalo-Magné, Bargaining over Residential Real Estate: Evidence from England, September 2002

$779 \mathrm{Yu}-\mathrm{Fu}$ Chen and Michael Funke, Exchange Rate Uncertainty and Labour Market Adjustment under Fixed and Flexible Exchange Rates, September 2002

780 Michael S. Michael, International Migration, Income Taxes and Transfers: A Welfare Analysis, September 2002

781 Clemens Fuest and Alfons Weichenrieder, Tax Competition and Profit Shifting: On the Relationship between Personal and Corporate Tax Rates, October 2002

782 Jan Bouckaert and Hans Degryse, Softening Competition by Enhancing Entry: An Example from the Banking Industry, October 2002

783 Johann K. Brunner and Susanne Pech, Adverse Selection in the Annuity Market with Sequential and Simultaneous Insurance Demand, October 2002 
784 Gregory D. Hess and Eduard Pelz, The Economic Welfare Cost of Conflict: An Empirical Assessment, October 2002

785 Jan Erik Askildsen, Uwe Jirjahn, and Stephen C. Smith, Works Councils and Environmental Investment: Theory and Evidence from German Panel Data, October 2002

786 Geir H. Bjønnes, Dagfinn Rime, and Haakon O. Aa. Solheim, Volume and Volatility in the FX-Market: Does it matter who you are?, October 2002

787 John Evans and John Fingleton, Entry Regulation and the Influence of an Incumbent Special Interest Group, October 2002

788 Wolfgang Ochel, International Comparisons and Transfer of Labour Market Institutions, October 2002

789 B. Gabriela Mundaca, Moral Hazard Effects of Bailing out under Asymmetric Information, October 2002

790 Gene M. Grossman and Edwin L.-C. Lai, International Protection of Intellectual Property, October 2002

791 John Hassler, José V. Rodriguez Mora, Kjetil Storesletten, and Fabrizio Zilibotti, A Positive Theory of Geographic Mobility and Social Insurance, October 2002

792 Paul De Grauwe and Marianna Grimaldi, The Exchange Rate in a Model with Heterogeneous Agents and Transactions Costs, October 2002

793 Guido Friebel and Mariassunta Giannetti, Fighting for Talent: Risk-shifting, Corporate Volatility, and Organizational Change, October 2002

794 Jan Erik Askildsen, Badi H. Baltagi, and Tor Helge Holmås, Will Increased Wages Reduce Shortage of Nurses? A Panel Data Analysis of Nurses' Labour Supply, October 2002

795 Marko Köthenbürger and Panu Poutvaara, Social Security Reform and Intergenerational Trade: Is there Scope for a Pareto-Improvement?, October 2002

796 Paul De Grauwe and Laura Rinaldi, A Model of the Card Payment System and the Interchange Fee, October 2002

797 Volker Böhm and Tomoo Kikuchi, Dynamics of Endogenous Business Cycles and Exchange Rate Volatility, October 2002

798 Mariam Camarero, Javier Ordóñez, and Cecilio Tamarit, The Euro-Dollar Exchange Rate: Is it Fundamental?, October 2002

799 Misa Tanaka, How Do Bank Capital and Capital Adequacy Regulation Affect the Monetary Transmission Mechanism?, October 2002 
800 Jörg Baten and Andrea Wagner, Autarchy, Market Disintegration, and Health: The Mortality and Nutritional Crisis in Nazi Germany, 1933-1937, October 2002

801 Saku Aura, Uncommitted Couples: Some Efficiency and Policy Implications of Marital Bargaining, October 2002

802 Wolfram F. Richter, Delaying Integration of Immigrant Labor for the Purpose of Taxation, October 2002

803 Gil S. Epstein and Shmuel Nitzan, The Politics of Randomness, October 2002

804 John Hassler and José V. Rodriguez Mora, Should UI Benefits Really Fall over Time?, October 2002

805 Friedrich Breyer and Stefan Felder, The Dead-anyway Effect Revis(it)ed, October 2002

806 Assar Lindbeck and Solveig Wikström, E-exchange and the Boundary between Households and Organizations, November 2002

807 Dieter Bös, Contests Among Bureaucrats, November 2002

808 Steven Brakman, Harry Garretsen, and Marc Schramm, The Strategic Bombing of German Cities during World War II and its Impact on City Growth, November 2002

809 Florian Englmaier and Achim Wambach, Contracts and Inequity Aversion, November 2002

810 Sarbajit Sengupta, Delegating Recruitment under Asymmetric Information, December 2002

811 Rajshri Jayaraman, On the Partial Public Provision of a Private Good, December 2002

812 Stéphanie Stolz, Banking Supervision in Integrated Financial Markets: Implications for the EU, December 2002

813 Christian Keuschnigg, Taxation of a Venture Capitalist with a Portfolio of Firms, December 2002

814 Inés Macho-Stadler and David Pérez-Castrillo, Settlement in Tax Evasion Prosecution, December 2002

815 Rainer Niemann and Dirk Simons, Costs, Benefits, and Tax-induced Distortions of Stock Option Plans, December 2002 